
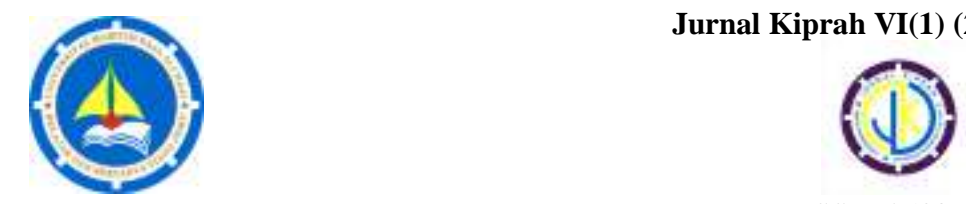

e-ISSN: $2580-6947$

p-ISSN: 2354-7278

http://ojs.umrah.ac.id/index.php/kiprah/index

\title{
USING CARD-SORT METHOD IN EFL WRITING CLASSROOM
}

\author{
Gatot Subroto $^{1^{*}}$, Vera Andriyani ${ }^{2}$ \\ ${ }^{1}$ Universitas Maritim Raja Ali Haji, Kota Tanjungpinang, Kepulauan Riau 29115, Indonesia \\ ${ }^{2}$ Institute of Miftahul Ulum for Islamic Studies, Kota Tanjungpinang, Kepulauan Riau 29125, \\ Indonesia
}

\begin{abstract}
This research was aimed at knowing the effectiveness of the card-sort method in teaching EFL writing. The writing was focused on descriptive text. The researchers used two groups of pre-test post-test experimental research design. The subject of this research was the eighth-grade students of SMP Negeri 24 Bintan. In this research, the researchers chose two classes, experimental and control classes, consist of 34 students by applying the purposive sampling technique. Writing test was used to gather the data needed. Based on the result of the statistic calculation, the result of the pre-test of the experimental class was 49 and the control class was 54 while the result of post-test was 70 for the experimental class and 64 for the control class. The $t_{\text {count }}$ was 4.881 with significant level 0.05 . Based on the data analysis, the researchers concluded that sig $0.000<0.05$ which meant there was the effectiveness of the card-sort method in teaching EFL writing.
\end{abstract}

Keywords: effectiveness, card-sort method, EFL writing classroom, descriptive text

\section{INTRODUCTION}

Nowadays, education is very important for everyone. Education can make a better life. Education is very important especially for the students from the child until adult even they should pay expensive to get the best education. Education is a process in order to influence students to adjust to the environment thus it will cause a change in the students' own education. Education can be gotten everywhere so, the main part when the people want to get the best education, they must know many languages to communicate with others.

There are many languages in this world, one of them is English. English has become the dominant language for science, technology, communication, and other fields, therefore, everyone needs to have the ability to use English. This realization makes many countries bring the teaching of English into their primary subject of education includes Indonesia. In Indonesia, I *Penulis Korepondensi ish Email Address : gatot.subroto@umrah.ac.id is also an important subject in our country which is learned from junior high schools until universities and some elementary schools. There are four basic skills in English, such as reading, speaking, listening and writing.

According to Brownie (2007), writing is a complex activity which involves many skills. It includes deciding what one wants to write, how best to say it and how to put these ideas onto paper in a way that is readable to others. Writing is very important as a media of communication. It can help students to have a good socialization which can express their idea, feeling and their opinion, so that they can have a good interaction with their society.

Teaching writing is not an easy task for the teacher because many students are still difficult and do not interest in learning English. The students are difficult to express their ideas in writing. So, the teacher must think hard how to 
arouse their interest in learning English, especially in writing.

However, in fact, the researchers found the eighth-grade students of SMP Negeri 24 Bintan have some problems. First, the students were not interested in learning English. They did not give attention when the teacher explained the material because they thought that English was not their language. Second, they felt bored during the teaching-learning process. In the learning process, the teacher explained the material and then asked students to do the exercise. Third, they were difficult in writing descriptive text. The teacher asked students to make a paragraph of descriptive text but the students could not express their idea and they confused what they will write.

Fourth, they were not confident in their ability in English. They felt afraid when they make some mistakes. Fifth, the teacher always used the monotonous technique in the learning process. Sixth, the students were difficult in reading some English sentences. They were difficult to pronounce some words when they read some English sentences. Seventh, the students were a lack of vocabulary. When they want to speak English, they looked for the English words that they want to speak in the dictionary because they did not have many vocabularies.

In the learning process, the teacher must think hard how to make students enjoy learning English, so they will receive the material well. From the explanation above, the researchers conclude that writing is one of the important skills in learning English. There are many texts that can be used in teaching writing, one of them is descriptive text. Bear (2007) states that descriptive text is creating a picture, in words, or what a person, place, or thing is like.

In addition, to solve the problem above, there are so many methods can be used in teaching writing descriptive text. One of them is called card-sort method. Silberman (2005) states that the card-sort method is an active team-based strategy that can be used to teach concepts, classification characteristics, or product knowledge or is to review information. The researchers thought that this method is suitable for students in junior high school because they could learn with fun. They must find their friends who have the same category cards and be a team. Therefore, based on the introduction above, the researchers conducted this research to know the effectiveness of the card-sort method in teaching EFL writing descriptive text.

\section{THEORETICAL REVIEW}

The researchers used some theories as guidelines in conducting this research. Those are the meaning of a card-sort method, steps to use the card-sort method, the advantages, and disadvantages of using the card-sort method, types of card-sort, writing, and descriptive text.

\section{a. The Meaning of Card-Sort Method}

Card-sort method is an active learning. According to Silberman (2005), card-sort method is an active team-based strategy that can be used to teach concepts, classification characteristics, or product knowledge or to review information. Card-sort method makes them actively using the brain to find some idea so that, they can do not have any difficulties in turning the ideas into paper by a look at the card. Card-sort method can help students in the teaching-learning process. It can make students active and exited in the learning process. Students can express their idea by a look at the cards that have been arranged into a good picture. By the picture that they have arranged, they can make a descriptive text.

\section{b. Steps to Use Card-Sort Method}

Silberman (2005) proposes three steps in using the card-sort method. Those are:

a) The teacher gives the students an index card that contains information about a category.

b) The teacher asks the students to mill around the room and finds others whose cards fit the same category.

c) The teacher asks the students who have the same category cards to make a descriptive text based on the card that they have been arranged. 


\section{c. The Advantages and Disadvantages of Using Card-Sort Method}

According to Spencer \& Warfel (2004), there are some advantages and disadvantages in teaching and learning process using the card-sort method. The advantages of this method are:

a) It is simple to set up and easy to perform.

b) Its cost is cheap.

c) It does not need much time to perform.

d) It makes enthusiasm among the subjects. In addition, this method also has the disadvantages, namely:

a) It is difficult for the students to perform if they do not know much about the card and whole process.

b) It will not succeed if the students do not know the content or topic of the card.

c) There is no any right or wrong answer on the card.

d) It makes students difficult in sorting the card when the category is not clear.

\section{d. The Types of Card-Sort}

According to Spencer (2009), there are two types of card-sort, namely:

a) Open

Open card-sort is given cards to students or group and they can look at the card what is the topic of the card that they have.

b) Close

Close card-sort is given students or group cards that do not have categories and a set of categories so the students must put the category on the card that they have.

\section{e. Writing}

Writing is an opportunity, it allows students to express something about themselves, explore and explain ideas. Students can convey their ideas in their mind by organizing them into a good text so that the others know them and they can think critically. As follow is the definition of writing by some experts:

Brownie (2007) states that writing is a complex activity which involves many skills that includes deciding what one wants to write, how best to say it and how to put these ideas onto paper to makes others understand. Oshima \& Hogue (2007) argue that writing is a creative activity that includes some steps and it is not enough if only one step action. In addition, writing is an activity which is done by someone to convey ideas, opinions, etc. in order to "speak" with his/her readers (Subroto, 2015).

Writing is important to subject for the students because it helps them to tell their feelings and then practice them to put something in their mind onto a paper. Writing is an excellent communication tool that has been used by someone to express their feeling or idea about people, place, thing and so on. Writing is closely related to speaking not only in such item of content, an organization of ideas, and vocabulary but also the relationship of the ideas or the coherent with the other sentence.

Based on the explanation above, the researchers concluded that writing is media communication for students to make a good interaction with others and it includes some activity like create some idea in the paper and then develop it. Writing is the real human activity. Writing has been speculatively designated as coincidental. Any person is capable of making or creating a piece of writing. Some people may even decide to publish a story or message.

\section{f. Descriptive Text}

Based on the curriculum of junior high school which is recommended by the Indonesian government, there are some texts that must be learned by students and one of them is descriptive text (Subroto \& Widharmanto, 2016). Description presents sensory information that makes writing come alive. It expresses an experience that the reader can actively participate in by using imagination.

There are some other definitions of the descriptive text proposed by experts. According to Bear (2007), descriptive text is creating a picture, in words, or what a person, place, or thing is like. Bima et.al. (2015) state that descriptive text focuses on the characteristic features of a particular thing such as a person, object or place. The other definition from Priyana et.al. (2008), the descriptive text describes the 
characteristics of a specific thing, for example, a specific person, animal, or object.

\section{g. Previous Study}

There was a previous research discussed card-sort method. Hidayati (2011) conducted a research on students' difficulties in understanding grammar in MAN Babakan Lebaksiu Tegal. Her research's purposes were (1) to describe the use of card sort in teaching conditional sentence at second grade of MAN Babakan Lebaksiu Tegal, and (2) to identify the improvement of students' understanding in learning conditional sentence through card sort at second grade of MAN Babakan Lebaksiu Tegal. The results of the study showed that using card sort can improve students' understanding on a conditional sentence. This was proved by students' understanding that was improved in every cycle. In the pre-cycle, the average of students' score was 54.125. In the first cycle, the students got 68.375 and in the second cycle, students got 79.125 .

\section{RESEARCH METHOD}

The method that used in this study was an experimental design. It means that the researchers investigated and analyzed the data which would be obtained after giving the treatment to the subject.

In this case, the researchers used two groups pre-test post-test design as proposed by Neolaka (2014). The figure of this design can be seen as follow:

\begin{tabular}{|llll|}
\hline $\mathrm{E}$ & $\mathrm{T}_{1}$ & $\mathrm{X}$ & $\mathrm{T}_{2}$ \\
$\mathrm{~K}$ & $\mathrm{~T}_{1}$ & & $\mathrm{~T}_{2}$ \\
& & & \\
\hline
\end{tabular}

The subject of this research was the eighthgrade students of SMP Negeri 24 Bintan. The researchers used 27 students of VIIA as experiment class and 27 students of VIIIB as control class.

In this paper, one technique used by the researchers to collect the data needed, i.e. test. According to Arikunto (2010), the test is a set of questions or exercises as well as other tools that are used to measure the skill, knowledge, ability or talent intelligence that is owned by an individual or group. The test was divided into two types, namely pre-test, and post-test. The pre-test was given before the treatment, and post-test was given after the treatment. The researchers used a subjective test.

In analyzing the collected data, the researchers used the quantitative method. It was said so because the data gathered were in the form of numbers, i.e. the students' pre-test, and post-test scores. The researchers used a T-test proposed by Sudjana (2002), to figure out the effectiveness of the card-sort method in teaching EFL writing. The T-test formula was as follows:

$$
t=\frac{\bar{x}_{1}-\bar{x}_{2}}{S \sqrt{\frac{1}{n_{1}}+\frac{1}{n_{2}}}}
$$

\section{FINDINGS AND DISCUSSION}

Before analyzing the effectiveness of the card-sort method in teaching EFL writing, the researchers did some prerequisite steps. First, a normality test was done to figure out whether or not the gathered data of control and experimental classes come from normal distribution. The result was shown in the following table.

Table 1

Normality test

\begin{tabular}{|l|l|l|l|l|}
\hline \multirow{2}{*}{\multicolumn{2}{|c|}{ Treatment }} & \multicolumn{3}{|l|}{ Kolmogorov-Smirnov } \\
\cline { 3 - 5 } & & Statistic & Df & Sig. \\
\hline $\begin{array}{l}\text { Gain } \\
\text { Score }\end{array}$ & Experiment & .164 & 27 & .059 \\
\cline { 2 - 5 } & Control & .159 & 27 & .079 \\
\hline
\end{tabular}

a. Lilliefors Significance Correction

Based on the above table, it could be seen that the significance of the experimental class was 0.059 and control class was 0.079 . Those significances were higher than $\alpha(0.05)$. It meant the data come from normal distribution.

Second, the researchers analyzed the data homogeneity to figure out whether or not data of control and experimental classes were homogeneous. The result was as mentioned in the following table.

Table 2

Homogeneity test 


\begin{tabular}{|ll|l|l|l|l|}
\hline & & $\begin{array}{l}\text { Levene } \\
\text { Statistic }\end{array}$ & df1 & df2 & Sig. \\
\hline $\begin{array}{l}\text { Gain } \\
\text { Score }\end{array}$ Mased on & 3.448 & 1 & 52 & .069 \\
\hline
\end{tabular}

Based on the above table, it found that the significance was 0.069 and it was higher than $\alpha$
(0.05). In meant the variance in each group was homogeneous.

Third, the researchers analyzed the effectiveness of the card-sort method in teaching EFL writing. The result of the t-test calculation could be seen in Table 3 below.

Table 3. T-test calculation

\begin{tabular}{|c|c|c|c|c|c|c|c|c|c|c|}
\hline & \multicolumn{2}{|c|}{$\begin{array}{l}\text { Levene's Test } \\
\text { for Equality of } \\
\text { Variances }\end{array}$} & \multicolumn{7}{|c|}{ t-test for Equality of Means } \\
\hline & & \multirow[b]{2}{*}{$\mathrm{F}$} & \multirow[b]{2}{*}{ Sig. } & \multirow[b]{2}{*}{$\mathrm{T}$} & \multirow[b]{2}{*}{ Df } & \multirow[b]{2}{*}{$\mid \begin{array}{l}\text { Sig. } \\
\text { (2-tailed) }\end{array}$} & \multirow[b]{2}{*}{$\begin{array}{l}\text { Mean } \\
\text { Differenc } \\
\text { e }\end{array}$} & \multirow[b]{2}{*}{$\begin{array}{l}\text { Std. Error } \\
\text { Differenc } \\
\mathrm{e}\end{array}$} & \multicolumn{2}{|c|}{$\begin{array}{l}95 \% \text { Confidence } \\
\text { Interval of the } \\
\text { Difference }\end{array}$} \\
\hline & & & & & & & & & Lower & Upper \\
\hline $\begin{array}{l}\text { Gain } \\
\text { Score }\end{array}$ & $\begin{array}{l}\text { Equal } \\
\text { variances } \\
\text { assumed }\end{array}$ & 3.448 & .069 & 4.881 & 52 & .000 & 10.778 & 2.208 & 6.347 & 15.209 \\
\hline & $\begin{array}{l}\text { Equal } \\
\text { variances } \\
\text { not } \\
\text { assumed }\end{array}$ & & & 4.881 & 47.714 & .000 & 10.778 & 2.208 & 6.337 & 15.219 \\
\hline
\end{tabular}

Based on table 3 above, it found that significance (2-tailed) was 0.00 and it was higher than $\alpha$ (0.05). In conclusion, the alternative hypothesis (Ha) was accepted. In another word, there was an effect of using card-sort method teaching EFL writing.

\section{CONCLUSION}

Based on the discussion in the previous section, the researchers concluded that there was the effectiveness of the card-sort method in teaching EFL writing. It was proved by the result of the t-test. The t-test showed that Significance (2 tailed) in t-test table was 0.000 , with significant level 0.05 . Therefore, it could be seen that $0.000<\alpha(0.05)$ which meant $\mathrm{Ha}$ was accepted. In another word, there was an effect of the card-sort method in teaching EFL writing.

Based on the conclusion above, the researchers believe that by applying the cardsort method in teaching learning process, especially in EFL writing, the teachers will achieve the teaching-learning goals and help their students feel easy to express their idea in written form and the class will be more enjoyable.

\section{REFERENCES}

Arikunto, S. (2010). Prosedur penelitian. Jakarta: Rineka Cipta.

Bear, R. D. (2007). Grammar and writing handbook. New York:

Macmillan/McGraw-Hill.

Bima, B. M., \& et.al. (2015). PR Bahasa Inggris kelas VIII semester 1. Klaten: 
JURNAL KIPRAH, Juni 2018; V1(1): 35-40

e-ISSN: 2580-6947

p-ISSN: 2354-7278

Intan Pariwara.

Brownie, A. (2007). Teaching and learning communication language and literacy. London: Paul Chapman Publishing.

Hidayati, P. (2011). The use of card sort to improve students' understanding on conditional sentence (a classroom action research at the eleventh-grade students of MAN Babakan Lebaksiu Tegal in the academic year 2010/2011. IAIN Walisongo.

Neolaka, A. (2014). Metode penelitian dan statistik. Bandung: Remaja Rosdakarya.

Oshima, A., \& Hogue, A. (2007). Introduction to academic writing, Third edition. New York: Pearson Education, Inc.

Priyana, J., \& et.al. (2008). Scaffolding English for junior high school students. Jakarta: Pusat Perbukuan Departemen Pendidikan Nasional.

Silberman, M. (2005). 101 ways to make training active. USA: Pfeiffer.

Spencer, D. (2009). Card sorting designing usable categories. New York: Rosenfeld Media.

Spencer, D., \& Warfel, T. (2004). Card sorting: A definitive guide. Retrieved from http: //boxesandarrows.com/cardsorting-a-definitive-guide/

Subroto, G. (2015). Teaching Writing of Procedural Text by Using Pictures. TABIR, I(2), 1-11.

Subroto, G., \& Widharmanto, B. (2016). Teaching writing descriptive text by using STAD model. KIPRAH, 4(2).

Sudjana. (2002). Metoda statistika. Bandung: Tarsito. 